\title{
Mechanism of Noise Generation in a Wing Profile Centrifugal Blower
}

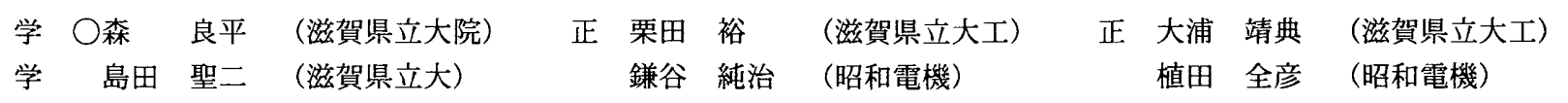

Ryohei MORI, The University of Shiga Prefecture, 2500 Hassaka-cho, Hikone-shi, Shiga

Yutaka KURITA, The University of Shiga Prefecture

Yasunori OURA, The University of Shiga Prefecture

Seiji SHIMADA, The University of Shiga Prefecture Junji KAMATANI, Showadenki Company

Masahiko UEDA, Showadenki Company

\section{1. 绪 言}

本研究では, 翼形遠心送風機の発生騒音の中でも音圧レベ ルの大きい, 翼通過周波数 (Blade Passing Frequency, 以下BPF) 騒音とケーシング内共鳴に着目する. まず，BPF騒音の発生 メカニズムを舌部付近での流れの可視化と圧力測定により解 明する. また, ケーシング内共鳴をスピーカーの白色雑音か ら送風機騒音の伝達関数により確認する。

\section{2. 形速心送国機}

対象とした翼形遠心送風機の概略図をFig. 1に示す. 設計仕 様は, 定格回転数 $3450 \mathrm{rpm}$, 出力 $0.75 \mathrm{~kW}$, 最大風量 $40 \mathrm{~m}^{3} / \mathrm{min}$, 最大静压 $1.65 \mathrm{kPa}$, 羽根車外径 $280 \mathrm{~mm}$, 翼枚数 10 枚, 吸込口は ベルマウス形状である.

無響室で送風機を実回転数3600rpmで運転し，ケーシングあ り,なし (羽根車単体)，それぞれの状態で発生騒音を周波数 分析した. 発生騒音を, 送風機中心軸上で吸込み口から $1.0 \mathrm{~m}$, 高さ $1.0 \mathrm{~m}$ の地点に設置した精密騒音計を用いて測定し，FFT アナライザを用いて周波数分析した. 測定結果をFig. 2に示す 測定結果から，ケーシングなしでは約 $900 \mathrm{~Hz}$ でのピークが確 認でき， $2500 \mathrm{~Hz}$ 以上では音圧が隇少している．ケーシングあ りでは，BPF成分である $600 \mathrm{~Hz}$ のピークが確認できる．また， ケーシング内共鳴の影響による約 $150 \mathrm{~Hz}$ を基本とした 3 倍, 5 倍のピークが確認できる.

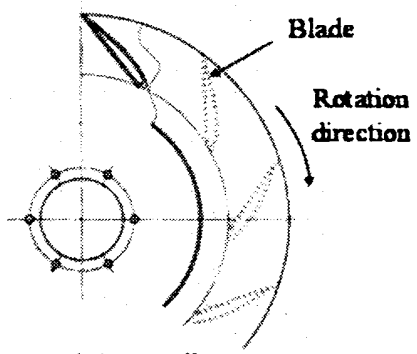

(a) Irnpeller

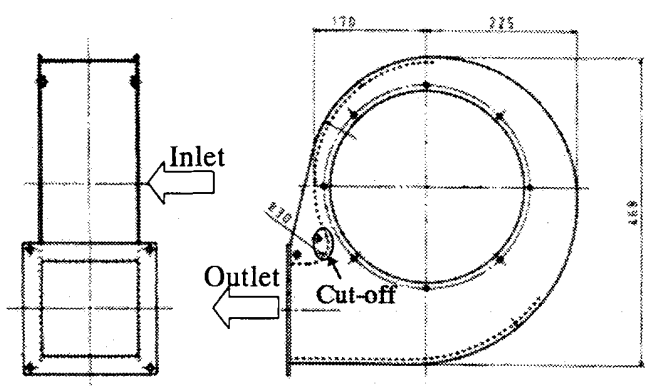

(b) Casing

Fig. 1 Wind profile centrifugal blower

\section{3. 卓通過周波数（BPF）展音}

舌部付近の流れを把握するために, 注入トレーサ法により 可視化実験をおこなった．透明なケーシングの送風機を実回 転数3600 rpmで運転し, 高速度カメラ, フォグマシン, 可視化 用シート光源を用いて可視化した. 可視化結果から, 流れの 方向は羽根車から舌部へ水平に流れ，これが翼通過に伴い速 度変動することがわかった。

舌部での圧力変動の発生要因を明らかにするために, 舌部 先端の圧力変動と翼位置との時間的関係を取得した。測定結 果から, 翼先端の通過後に約 $0.53 \mathrm{~ms}$ 遅れて最大圧力となるこ とがわかった．このことから，舌部の圧力変動の主な発生要 因が翼通過に伴う速度変動であると言える.

\section{4. ケーシング内共啨}

ケーシング内共鳴を確認するため, ケーシング内に設置し たスピーカーから白色雑音を出力し, 吸込口から $1.0 \mathrm{~m}$ 地点の 騷音との伝達関数を取得した。.また，プローブマイクロホン を用いてケーシング内部の压力分布を測定し，共鳴モードを 調べた. 測定結果から，2つの基本モードが存在することがわ かった．その周波数は $144 \mathrm{~Hz} ， 168 \mathrm{~Hz}$ であり，それぞれが奇数 倍のピークをもつことを確認した.

\section{5. 結}

（1）翼形遠心送風機騒音は，羽根車単体の乱流騒音，BPF 騒 音, ケーシング内共鳴の要素で構成される.

(2) BPF 騒音は翼通過に伴う速度変動が舌部で圧力変動に変 わり発生する。

(3) ケーシング内において共鳴現象が発生しており，2 つの 基本モードが存在する.

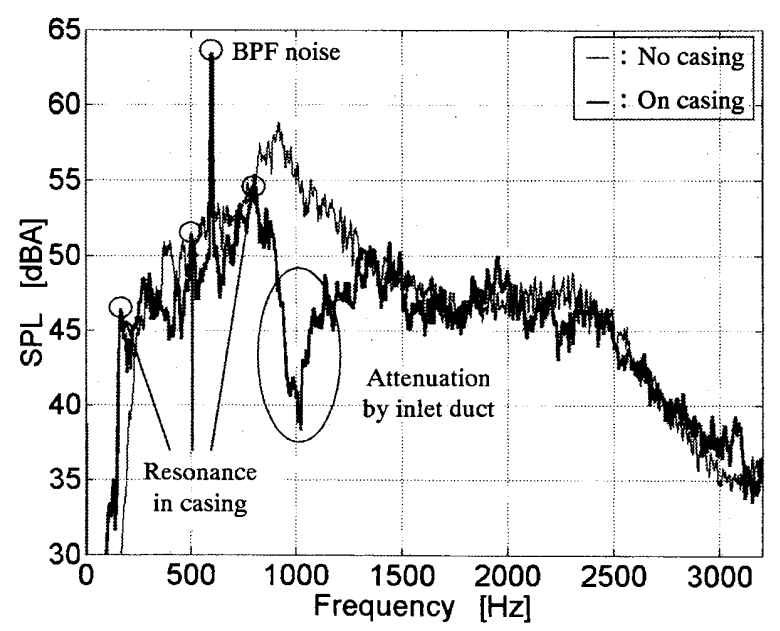

Fig. 2 Frequency analysis of noise 